1980

\title{
The Legal Status of the Psychologist in the Courtroom
}

Michael L. Perlin

New York Law School, michael.perlin@nyls.edu

Follow this and additional works at: https://digitalcommons.nyls.edu/fac_articles_chapters

Part of the Law and Psychology Commons

\section{Recommended Citation}

Mental Disability Law Reporter, Vol. 4, Issue 3 (May-June 1980), pp. 194-200

This Article is brought to you for free and open access by the Faculty Scholarship at DigitalCommons@NYLS. It has been accepted for inclusion in Articles \& Chapters by an authorized administrator of DigitalCommons@NYLS. 


\title{
The Legal Status of the Psychologist in the Courtroom
}

\author{
by Michael L. Perlin
}

$\mathbf{I}_{\mathrm{p}}^{\mathrm{n}}$ $\mathbf{n}$ the practice of law, just as in the practice of other professions or trades, it is often the mores and customs which deserve the attention usually paid to the written rules of substance and procedure. Although thousands of words are written about the subtle points of a significant court decision or statutory revision, usually limited analysis is given to what can be termed the "socialization of the law."

A discussion of the legal status of the psychologist in the courtroom should begin with the premise that the phrase legal status encompasses at least three issues: the legal status of the psychologist as defined by case law (i.e., when he or she can give expert testimony); the legal roles which a psychologist can fill (i.e., the kinds of cases in which he or she can testify); and the social status of the psychologist in the courtroom (i.e., how he or she is viewed by the judge, the jury, the parties, other experts and other psychologists themselves). Although case law is now becoming relatively uniform and the scope of witness roles is widening, it is the social status of psychologists in the courtroom - a question largely ignored which is probably the most important of these three topics.'

\section{Jenkins Establishes Legal Status of Psychologists}

Although a few early cases held that a properly qualified psychologist could testify in a criminal trial on questions involving mental condition or competency to stand trial ${ }^{2}$ or in accident disability cases on questions of extent of neurological impairment, ${ }^{3}$ it was not until the 1962 decision of the District of Columbia Court of Appeals in Jenkins $v$. United States ${ }^{4}$ that the psychologist's legal status was given firm grounding.

In Jenkins, a criminal case in which the defendant on trial for housebreaking with intent to assault raised the insanity defense, the trial judge had ordered the jury to disregard the testimony of defense psychologists that the defendant "had a mental disease" when he committed the crimes in question because "a psychologist is not competent to give a medical opinion as to a mental disease or defect."'s Following the jury's conviction, however, the court of appeals reversed and remanded the matter for a new trial based

Michael Perlin is the director of New Jersey's Division of Mental Health Advocacy of the Department of the Public Advocate. This article has been adapted from a paper prepared for the 1979 American Psychological Association's annual meeting. on a series of errors, including that the ruling by the trial judge was incorrect, since "some psychologists are qualified to render expert testimony in the field of mental disorder." 6

Judge David L. Bazelon, speaking for a sharply divided court, noted that the appropriate test was "whether the opinion offered will be likely to aid the trier in the search for truth." 7 The answer to this test will not "depend upon [the witness'] claim to the title 'psychologist,' "8 the court warned. Rather, the determination must depend "upon the nature and extent of his knowledge."9 While psychologists otherwise employed in areas such as personnel administration or industrial relations might not qualify to testify as to "mental disease or defect," a psychologist with a doctorate in clinical psychology who has had a psychiatric hospital internship and/or completed an American Psychological Association-approved graduate training program and/or is board certified might properly testify. ${ }^{10}$

As indicated, the opinion was not unanimous. In a special concurring opinion, Judge (now Chief Justice) Warren Burger criticized Judge Bazelon's opinion for its alleged "[failure] to give adequate guidance as to the scope and nature of the inquiry" on remand. " $\mathrm{He}$ listed seven major areas of concern, such as the scope of the specific psychologist's clinical education in "physiological and medical subjects," his ability to "[prescribe] or [supervise] treatment of mental patients," and the meaning of "clinical experience," 12 which should be covered. ${ }^{13}$ Two other judges also dissented, urging the court to accept the position of amicus curiae American Psychiatric Association, which had argued that psychologists should not be allowed to qualify as experts. ${ }^{14}$ According to the dissenters, the majority should have listened to the "wise counsel from the only undisputed experts now at work in the area of medical illness of the mind." 15

Following Jenkins - a case which, by the way, met with nearly unanimous critical endorsement in the scholarly legal journals ${ }^{16}$ - virtually every major criminal decision has echoed its language, ${ }^{17}$ thus strengthening the psychologist's "legal status." Although at least one state's highest court has suggested that a psychologist is "professionally inferior" to medical doctors, ${ }^{18}$ recent decisions have approved of the reasoning of the Jenkins court. Some decisions have allowed the admission of testimony where the witness's "training, experience, information and personal observation" of the defendant ${ }^{19}$ satisfied the 
"nature and extent of his knowledge," a test suggested by Judge Bazelon in Jenkins, ${ }^{20}$ while others have denied its admissibility in cases where, for example, the erstwhile witness was a "psychology technician" with a bachelor's degree and less than a year's work experience. ${ }^{21}$ The language of a Wisconsin court on this point is pertinent:

[l]f a person has qualifications in a field, he may testify within his area of competency. As the frontiers of knowledge are pushed back, we find it increasingly difficult to compartmentalize many areas of knowledge with exclusiveness. It is the particular qualifications of the witness in relation to the particular issue which should control rather than the label of a profession or trade. 22

The language in cases of this sort is not merely hortatory. In Illinois, for instance, courts have been meticulous in examining and evaluating the specific credentials of witnesses sought to be produced in a series of $\operatorname{cases}^{23}$ in accordance with the Jenkins guidelines.

\section{Doors Opened to Admission}

of Psychological Testimony

In addition to extending psychological testimony beyond the scope of criminal responsibility issues to encompass cases involving issues such as incompetency to stand trial, ${ }^{24}$ the Jenkins line has significantly expanded psychologists' role in the courtroom in negligence/automobile accident cases that involve accuracy of personality tests ${ }^{25}$ and presence of organic brain disease. ${ }^{26}$ In a Pennsylvania case involving organic brain damage, ${ }^{27}$ after citing Jenkins with approval, ${ }^{28}$ the court went one step further and, based on the testimony of a consulting neurosurgeon in the case and what it characterized as "present medical and psychological practice,"'29 found that testimony of "non-medical practitioners may be not only desirable but necessary." 30

But this trend is not unanimous. Maryland recently rejected another attempt to liberalize its rules on admissibility, choosing instead to limit psychological testimony to interpretations of psychological tests (e.g., WAIS, Rorschach, Bender-Gestalt) and to exclude testimony as to causes of psychological deficiencies. ${ }^{31}$

Jenkins and its progeny, then, literally opened the doors to the admission of psychological testimony in many legal areas. Psychologists now commonly testify as expert witnesses in civil commitment matters involving questions of retardation, acceptability of treatment involving behavior therapy and appropriateness of placements. ${ }^{32}$ They are also increasingly involved in such issues as employment discrimination, ${ }^{33}$ juvenile placements, ${ }^{34}$ accuracy in evaluation of eyewitness testimony, ${ }^{35}$ special education assignments, ${ }^{36}$ effects of bilingualism on children, ${ }^{37}$ postsentencing disposition, ${ }^{38}$ extent of neurological injury,,$^{39}$ community standards in obscenity prosecutions, ${ }^{+0}$ trademark infringements and fraudulent advertising suits. ${ }^{4}$ Even more importantly, perhaps, psychologists are beginning to testify in class actions involving such fundamental issues as right to education, ${ }^{42}$ right to habilitation, ${ }^{43}$ and right to vote. ${ }^{44}$ Such testimony continually expands the legal influence of psychologists. According to psychologist Cameron Fincher, if the psychological community wishes to evince a "consistent concern with the social, cultural and humanistic issues as well as the professional and technical problems, "45 then it must critically involve itself in these roles.

Perhaps the most prominent recent example of the use of psychological testimony is the now-famous Pennhurst case. ${ }^{46}$ There, psychologists testified on a full range of issues before the court, including education, training, care, habilitation, staffing, restraints, psychopharmacological problems, abuse, and availability of alternative facilities. ${ }^{47}$ This testimony was crucial in shaping the court's ground-breaking opinion that the equal protection clause of the Constitution "prohibit[ed] the segregation of the retarded in an isolated institution such as Pennhurst where habilitation does not measure up to minimally adequate standards," 8 and "immediate steps [must] be taken to remove the retarded residents from Pennhurst"49 commensurate with the exercise of "great caution and care." 50 Involvement in this sort of case is telling evidence of the sort of "social, cultural and humanistic [concern]"'s1 referred to and urged by Dr. Fincher.

At the same time, however, the pertinency of the simple truism, suggested in an article on courtroom psychiatry by attorney Bernard Diamond and psychiatrist David Louisell, that "the psychological sciences differ from the biological sciences in that the subject matter of the former is not visible".52 is even more applicable to a discussion of forensic psychology and the role of the courtroom psychologist. What are often viewed as the "excesses" of flamboyant expert witnesses in public spectacles such as the Hearst or Ruby trials ${ }^{53}$ quickly become transformed into sins visited upon all expert witnesses. Papers are regularly published denying the need for involvement of "adversarial" experts in the legal adversary process, ${ }^{54}$ direly forecasting the inevitable prostitution of the profession, ${ }^{55}$ questioning the compatability of psychology, psychiatry and the courts,,$^{56}$ and recommending that experts only become involved on an amicus (friend of the court) or so-called impartial witnesses level. ${ }^{57}$ Although these positions have been more than adequately responded to by lawyers ${ }^{58}$ and psychiatrists, ${ }^{59}$ a backlash phenomenon is clearly present. $^{60}$

\section{Psychologists Viewed as "Second-Class Experts"}

Beyond this, however, lurks an even more disturbing problem for forensic psychologists. Not only must they contend with the same basic antipathy in the courtroom facing psychiatrists, ${ }^{61}$ they must also contend with what is perceived as a "second-class expert" status when compared by judge or jury to med- 
ical experts. Thus, a basic legal text points out that "a favorite trick of cross-examination is to bring out the lack of medical education of the clinical psychologist ... in a voice oozing [with] incredulity or sarcasm. ${ }^{62}$ Elsewhere, it has been pointed out that psychologists may sometimes be effectively baited by attorneys "indirect [ly] attempt [ing] to question [their] qualifications and competence .. . by addressing [them] always as 'Mister.' in marked contrast to the consistent and appropriate use of the title Doctor." "633 One of the post-Jenkins decisions notes, for example, that the trial court had asked the psychologist-witness. "You have never dissected a cadaver, have you?" "64 In another more recent case, in an attempt to discredit a clinical psychologist who had testified as a defense witness, the prosecutor ap-

\section{Study shows psychologists' testimony is "first rate"}

The following is excerpted from a paper delivered at the 1979 American Psychology-Law Society meeting by clinical psychologists Dr. Norman G. Poythress, Jr., and Dr. Russell Petrella. Both work for the Center for Forensic Psychiatry in Ann Arbor, Michigan, which handles forensic referrals from the district and circuit courts throughout the state regarding issues of competency to stand trial and criminal responsibility. Its staff includes psychiatrists, social workers and psychologists.

Though the nonmedical mental health professionals are gaining parity with psychiatrists in terms of their legal status (i.e., admissibility to testify as "experts"), Michael Perlin points out that nonpsychiatric experts may suffer from decreased social status in the eyes of the judge or jury they may be perceived as "second-rate" experts. Psychiatrists may be presumed, based on the fact of medical training or on other untested assumptions, to do more thorough or higher quality work than nonmedical examiners. While reasoned arguments have asserted that none of the mental health professions has forensic expertise not shared by the others, to our knowledge there have been no empirical "studies to date comparing the various disciplines in terms of the quality of forensic eväluations.

The results of our three studies address the issue of the thoroughness and quality of forensic examinations performed by medical versus nonmedical mental health examiners and the issue of whether the trier of fact perceives the psychologist as a "seconid-rate" expert.

In the first study. we randomly selected clinical evaluations of defendants referred for competency to stand trial or criminal responsibility which had been completed between August, 1975, and September, 1978. These reports, done by psychiatrists, psychologists and social workers, were scrutinized regarding the thoroughness of the evaluation as measured by the amount of effort and information reflected in the casebook.

Since a longer report is not necessarily a higher quality report, we undertook a second study to address the issue of the quality of work performed by the various mental health disciplines. A "blind" sample of the reports from the first study were rated and ranked on qualitative factors by various legal professionals - a circuit court judge, a prosecuting attorney and a law school professor.

In the third study, we utilized records of court appearance and testimony maintained at the Forensic Center and looked at the outcome of those cases in which the defendant asserted the insanity defense. In these cases, the testimony of a Forensic Center psychologist was matched against an expert or battery of experts that included medical or psychiatric personnel.

The purpose of the three-study investigation was to test the assumption that the psychiatrists do more thorough or higher quality work. The results obtained demonstrate quite convincingly that this is a false assumption. There is no evidence to suggest that psychiatrists do higher quality work on any of the variables employed. To the contrary, psychiatrists' reports were consistently found to be shorter than those prepared by psychologists and social workers. Also the quality of the psychologists' and social workers' reports were consistently rated as equal to or better than the psychiatrists' reports. Thus, the psychologist and social worker status as "second rate". experts is unfounded when one evaluates the actual work they produce.

This study firmly supports the current trend to utilize nonmedical mental health professionals for court related evaluations. Although the results of the present study are limited by the small number of judges employed, one cannot ignore its implications. In the opinion of various legal experts, the evaluations completed by professionals other than psychiatrists were in no way second rate. Additional data demonstrated that in actual trial situations, psychologists' opinions regarding legal insanity were adhered to in 82 percent of the cases when a medical expert offered opposing testimony.

These findings on a practical level have significant economic implications, since psychiatric "time" is traditionally more expensive. The results suggest that the courts could obtain essentially the same product, and possibly a superior one, at less cost by utilizing nonmedical experts. 
pealed to the jury to disregard the witness's interpretation of a projective test:

Ladies and gentlemen, then we come to that ink blot.... Fourteen responses and four of them turned out to be anatomical things - hearts or whatever it happened to be. Is there something unusual about that? Is a man crazy when he sees a heart or something else four times. . . After all, they are just blots of ink. Is a man crazy when he sees them? And how about that last one, that rocket one. He says he sees a rocket going off. I asked him, Doctor, was there any rocket fired during that period of time that might stick in a man's brain and might suggest it to him? The doctor doesn't know, but there is something explosive about a personality if he sees a rocket on a little ink blot.

Well, ladies and gentlemen, there is not much 1 can say about that; I am not an expert. . . . But I can say one thing; that it is a jury decision. It is your province. It is your function to take that evidence and weigh that evidence and decide whether what the doctor said as far as you are concerned made any sense at all. ${ }^{65}$

In Jenkins, itself, in fact, a courtroom observer pointed out that during the course of a psychologist's testimony, the presiding trial judge "literally threw a deck of projective cards onto the floor." 66 Finally, a Jenkins analysis concluded by asking rhetorically:

[W that significance will the jury attach to the defense psychologist's testimony when confronted with the conflicting testimony of the state's psychiatrist? Will recitation to the jury of the psychiatrist's qualifications, which will include a medical degree, have any prejudicial effect on the defendant who produces a psychologist? [Emphasis added. $]^{67}$

The treatment of the problem and answers to these questions must be dealt with openly and completely by forensic psychologists. They must confront the reasons why they have been treated as second-class citizens in the court and why they sometimes see themselves in that role.

One tool in the psychologist's arsenal may be created by the legislatures on a state-by-state basis. I am referring to a strong privilege statute. In this regard, Pennsylvania law is clear and explicit:

A person licensed as a psychologist under the provisions of this act cannot, without the written consent of his client, be examined in a civil or criminal action as to any information acquired in the course of his professional services in behalf of the client. The confidential relations and communication between a psychologist and his client are on the same basis as those provided by law between an attorney and client, and nothing in this act shall be construed to require any such privileged communication to be disclosed. ${ }^{68}$

In Pennsylvania, then, the psychologist's legal status is a direct function of the strength of the psychologists' lobbying force in the statehouse, and the second-class expert argument is inappropriate. Take, for example, a Pittsburgh case in which a psychiatrist had been held in contempt for refusing to release psychiatric records of a patient to the court in a juvenile delinquency matter involving the patient's son. Although that had been the trial court's ruling, the contempt citation was reversed by the Pennsylvania Supreme Court ${ }^{69}$ on the grounds that such disclosure would have violated the patient's right to privacy, ${ }^{70}$ because the information in question was obtained "within the context of a psychotherapist-patient relationship." 71 Interestingly, this analysis was only necessary because, in Pennsylvania, the doctorpatient privilege statute ${ }^{72}$ was not as broad as the psychologist-client statute. ${ }^{73}$

Forensic psychologists must also be concerned with the forensic psychiatrists who are still uncomfortable about the newcomers" involvement, which is seen in some quarters as usurpation. Thus, in the case where the prosecution said, "After all, they are just blots of ink," the American Psychiatric Association filed an amicus brief clearly labeling such forensic psychologists as "laymen" in relation to the diagnosis of "mental illness or defects." 74 According to the eminent Professor of Law and Psychiatry Richard Allen, the American Psychiatric Association's ultimate objective is "quite clear: reversal of Judge Bazelon's decision in Jenkins. "75 This spectre must be a serious subject of consideration for the forensic psychologist.

It is clear that organized psychiatry is choosing to wage its war against organized psychology on many fronts, most notably in defending against psychologists' challenge of third-party payment plans based on "freedom of choice" grounds. ${ }^{76}$ Although this is not a "courtroom" issue per se, its significance should not be understated.

\section{Social Status a Reflection of Self-Perceptions}

The genesis of the "second-class expert" attitude cannot be laid solely, or even, perhaps, predominantly, at the feet of the legal or psychiatric profession. This social status can be seen as a reflection on the selfperceptions held by many psychologists of their potential courtroom role. Although it was a lawyer who noted that the traditional limitation in courtroom participation "comes not only from the law, but also from the inhibitions of psychologists, " 77 it is clearly very often the "fault" of the psychologists themselves that their forensic role has been so truncated. Indeed, psychiatrist Louisell's observation some twenty years ago that "psychologists ... often seein to display an undue hesitancy, amounting almost to fear, to taking the witness stand, $" 78$ is still all too valid in many instances. ${ }^{79}$

Douglas Sargent, a psychiatrist, has noted that a forensic psychiatrist is "annoyed by the limitations which legal procedures place on his testimony, impatient with the stilted rituals of courtroom etiquette, intrigued by the law's archaic language." This response, he says, creates an "unfortunate polarization of attitudes ... [leading to] a hostile parody of the 
truth." 80 The substitution of psychologist for psychiatrist in that sentence would similarly ring true.

In addition, forensic psychologists must confront the fact that they cannot "behave in the courtroom as though the issues were settled." 81 Transcripts sometimes reveal forensic psychological witnesses whose demeanors in important, otherwise well-prepared, serious criminal cases range from obstinate to condescending to patronizing to omniscient. ${ }^{82}$ In the vernacular, some forensic psychologists must "clean up their act."

Psychologists have become aware that they must learn how to deal with specific courtroom gambits if they are to survive on the witness stand..$^{83}$ Thus, the heralded Competency Screening Index, prepared by the Laboratory of Community Psychiatry in conjunction with the National Institute of Mental Health, establishes a sentence-completion test for the purpose of "quickly screening defendants" to make recommendations as to their competency to stand trial. ${ }^{84} \mathrm{It}$ is geared to determine whether an individual defendant meets the three-pronged, common-law test for competency (ability to cooperate with counsel, understand nature of proceedings, understand consequences of proceedings), and, in fact, may effectively do so. ${ }^{85}$ A witness, however, who administers and then testifies to the results of a test such as this must be aware of, and must be able to deal with, the pitfalls of probing cross-examination, a skeptical judge, and, on occasion, an incredulous jury.

One more point must be made. Although "propsychologist" courts have generally taken the position that "the qualification of an expert has historically been a matter not of licensure, but of experience ${ }^{86}$ the whole area of licensure is now subject to attack from consumer groups, economists and political scientists. They charge that licensing perpetuates "the return of medieval guilds," as it "significantly increases the cost of professional services, decreases the supply of practitioners, inhibits improvements in the organization and delivery of services, stifles innovative training programs, and is discriminatory." 87 Again, it will be necessary for thoughtful psychologists to deal with these charges.

\section{Involvement on Three Levels}

Although this picture looks gloomy, it should also be encouraging to forensic psychologists. The cases which I have referred to, especially the noncriminal ones, are an opportunity for psychologists to push for further involvement in the judicial process on at least three separate levels.

First, the special assessment, testing and intellectual/personality evaluation skills and techniques possessed by clinical psychologists uniquely prepare them for much courtroom work, ${ }^{88}$ such as in the areas referred to earlier, as well as such newly emerging areas as ferreting out cultural test biases. ${ }^{89}$ They will better be able to play this role if they become, in the phrase of psychologist Stanley Brodsky and psy- chiatrist Ames Robey, "courtroom-oriented" and discard their usual "courtroom-unfamiliar" pose. ${ }^{90}$

Secondly, it is clear that testimony in civil rights class actions gives the forensic psychologist a tremendous opportunity "to contribute to social change" $" 91$ as an "advocate and facilitator," $" 92$ while fulfilling his or her role as part of a "socially concerned system." 93 To further promote this socialchange model, psychologists have begun to work with lawyers, psychiatrists and former patients on such endeavors as the Task Force Panel on Legal and Ethical Issues of the President's Commission on Mental Health, ${ }^{94}$ and they have devoted full issues of their professional journals to the "emerging interface between law and psychology." "95 "Such joint participation will only expand in the future.

As a corollary to both of these reasons, it should also be pointed out that forensic psychologists are remarkably successful when they go to court. In 70 percent of a group of cases studied, the verdict was in favor of the side on which the psychologists testified. ${ }^{96}$

Finally, it is clear that the courts are ready for the forensic psychologist. As indicated earlier, legal barriers to testimony have virtually disappeared. ${ }^{97}$ One commentator calls the clinical psychologist "worthy of our consideration in the seeking of new and improved trial techniques."98 Another questions how long the law can "lag behind scientific fact and common knowledge," 99 and a third argues that the psychologist "can contribute in the courtroom toward a better understanding of emotional illness." 100 Interestingly, this final commentator points out how psychology's struggle for acceptance as a scientific and objective discipline familiarizes the psychologist with ways to overcome the shortcomings of such tools as projective tests and uniquely prepares him or her for the rigors of cross-examination. ${ }^{101}$ It thus remains only for the psychological community to openly confront the reasons which have perpetuated the anticourtroom bias and to educate all participants in the litigation process to the need for and uniqueness of appropriate psychological testimony. The recent creation of an American Board of Forensic Psychology can only aid in this educational process. ${ }^{102}$

In a 1961 article, Norma Scheflen, a research psychologist at Temple University, quoted the famous law dean John Wigmore as saying, "Whenever the psychologist is really ready for the courts, the courts are ready for him." ${ }^{103}$ Although 19 years ago Dr. Scheflen prophesized that "the time is now," it is unfortunate that history did not truly bear her out. Perhaps now, finally, it will.

\section{Footnotes}

\footnotetext{
- For a similar analysis, see Perlin, "Psychiatric Testimony in a Criminal Setting." 3 Bull. Am. Acud. Psych.\& L. 143 (1975).

2 See. e.g.. People r. Hawthorne. 291 N.W.2d 205 (Mich. Sup.
} 
Ct. 1974); State 1. Padilla, 347 P.2d 312 (N.M. Sup. Ct. 1959); Annotation. "Qualification of Non-Medical Psychologist to Testify as to Mental Condition or Competency," 78 A.L.R.2d 919 (1961). Contra, see. e.g.. Dobbs 1. State, 85 S.W.2d 694 (Ark. Sup. Ct. 1935): People r. Spigno. 319 P.2d 458 (Cal. Dist. Ct. App. 1957).

${ }^{3}$ See, e.g., Hidden 1. Mutual Life Ins. Co., 217 F.2d 818 (4th Cir. 1957).

4307 F.2d 637 (D.C. Cir. 1962).

$3 / d$. at 643 .

6 Id.

7 Id.

8 Id. at 645 .

9 Id.

$10 / d$. at 644-645.

11 Id. at 647-648.

$12 / d$. at 649-650.

13 Burger's views on psychiatry and psychology have been well recorded since. In an article in Federal Probation (Burger, "Psychiatrists, Lawyers and the Courts," 28 Fed. Prob. 3 (1967)), he stated:

At best psychiatry is now an infant among the family of sciences. Just as the law can lay no valid claim to being truly scientific, neither perhaps can psychiatry and psychology; they may be claiming too much in relation to what they really understand about the human personality and human behavior.

More recently, in a special concurring opinion in the landmark case of $O$ 'Connor ' '. Donaldson, 422 U.S. 573 (1975), he noted:

There can be little responsible debate regarding the "uncertainity of diagnosis in this field and the tentativeness of professional judgment." [Greenwood 1 . United States, 310 U.S. at 375. See also Ennis \& Litwack, "Psychiatry and the Presumptiom of Expertise: Flipping Coins in the Courtroom," 62 Calif. L. Rev. 693.]

The Chief Justice's reference to the Ennis article is fascinating. Simultaneously, by citing it, he hoists Ennis (Donaldson's counsel) on his own petard and dryly retums a compliment to Ennis who had concluded his California Law Review article by citing Burger's article in Federal Probation, referred to above. 62 Calif. L. Rev'. at 751-752, n. 204. Such Byzantine cross-citations should not go unnoticed.

14 Jenkins v. United States, 307 F.2d 637 (D.C. Cir. 1961) (Bastian, J., dissenting).

15 Id.

is See, e.g., Note, "Evidence - Criminal Insanity - Psychologist's Diagnosis Regarding Mental Disease or Defect Admissible on Issue of Insanity," 8 Vill. L. Rev. 119 (1962); Levitt, "The Psychologist: A Neglected Legal Resource," 45 Ind. L. Rev. 82 (1969); Lassen, "The Psychologist as an Expert Witness in Assessing Mental Disease or Defect," 50 A.B. $A J .239$ (1964). Cf., however, Morse, "Psychologist as Witness on Mental Incompetence," $198 J$ A .M A. 313 (1966).

17 See, e.g., United States v. Green, 373 F. Supp. 149 (E.D. Pa. 1974) ("The critical factor is the psychologist's actual experience and the probably probative value of his testimony"); Blunt $v$. United States, 389 F.2d 545 (D.C. Cir. 1967) (repeating "requisite training or experience" language); People v. Lyles, 526 P.2d 1332 (Colo. Sup. Ct. 1974); United States 1'. Riggleman, 411 F.2d 1190 (4th Cir. 1969) (determination depends on "the nature and extent of (psychologist's] knowledge"). Contra, see, e.g., People r. Gilliam, 306 N.E.2d 352 (III. App. Ct. 1974). Most relevant cases are discussed at Pacht et al.. "The Current Status of the Psychologist as an Expert Witness," 4 Prof. Psychol. 409 (1973). For recent specific applications of Jenkins, see, e.g.. United States '. Caldwell, 543 F.2d 1333 (D.C. Cir. 1974); United States 1. Portis, S42 F.2d 414 (7th Cir. 1976).

18 See, e.g., State v. Tull, 212 A.2d 729 (Md. Ct. App. 1965).

18 Rollins i. Commonwealth. 151 S.E.2d 622 (V.a. Sup. Ct. App. 1966).
20 307 F.2d, above, at 645.

21 Smith r. State. 234 S.E.2d 385 (Ga. Ct. App. 1977).

22 Roherts r. State, 164 N.W.2d 525 (Wis. Sup. Ct. 1969)

${ }^{23}$ Cf.. e.g. People r. Noble. 248 N.E.2d $\%$ (IIl. Sup. Ct. 1969), to Gilliam, 306 N.E.2d, above, at 356, to Matter of Wollington, 340 N.E.2d 31 (III. Dist. App. Ct. 1975) (civil commitment case), to People r. Manning. 378 N.E.2d 227 (III. Dist. App. Ct. 1978).

24 See, e.g.. People '. Cranford. 239 N.W.2d 670 (Mich. Ct. App. 1976) (distinguishing case from People 1. Skowronski, 232 N.W.2d 306 (Mich. Ct. App. 1975), in which same court held that a social worker was not qualified to evaluate psychological tests given a defendant, noting that "a social worker, unlike a psychologist, does not have the training or expertise to administer and evaluate psychological tests," 239 N.W.2d at 672, n. 2).

${ }^{25} \mathrm{Karl} \because$. Employers Insurance of Wausau, 254 N.W.2d 255 (Wis. Sup. Ct. 1977).

${ }^{26}$ Buckler 1 . Sinclair Refining Co., 216 N.E.2d 14 (1II. Dist. App. Ct. 1966); Indianapolis Union Railway r. Walker, 318 N.E.2d 578 (Ind. Ct. App. 1974).

27 Simmons '. Mullen, 331 A.2d 892 (Pa. Sup. Ct. 1974).

29 Id. at 898, citing Jenkins, 307 F.2d, above, at 644 .

29 Simmons, 331 A.2d, above, at 899.

30 Id. at 898.

31 Spann v. Bees, 327 A.2d 801 (Md. Ct. Spec. App. 1974), cert. denied (1975).

32 See generally Martin, Legal Challenges to Behavior Modification (1975). For a specific example, see Wellington, above.

33 See Fincher. "Personnel Testing and Public Policy," $28 \mathrm{Am}$. Psychologist 489 (1973).

34 See, for a forceful critique, Sussman, "Psychological Testing and Juvenile Justice: An Invalid Judicial Function," $10 \mathrm{Crim} . \mathrm{L}$. Bull. 117 (1974).

ss See Lezak, "Some Psychological Limitations on Witness Reliability," 20 Wayne L. Rev. 117 (1973).

36 See, e.g., Kirp and Kirp, "The Legalization of the School Psy. chologist's World," 14 J. School Psychol. 83 (1976): Katz and Bonfield, "The Right to Education: Due Process and the Inner City Child," 3 Bull. Am. Acad. Psych. \& L. 70 (1976); Kirp, Buss and Kuriloff, "Legal Reform of Special Education: Empirical Studies and Procedural Proposals," 62 Culif. L. Rev. 40 (1974); Gorlow, "The School Psychologist as Expert Witness in Due Process Hearings," 13 J. School Psychol. 311 (1975).

37 See, e.g., Rose, "The Social Scientist as an Expert Witness," 40 Minn. L. Rev. 205 (1956); Kendler, "Contributions of the Psychiatrist to Constitutional Law," 5 Am. Psychologist 505 (1950).

38 See, e.g., Brodsky. Psychologists in the Criminal Justice System 93-101 (1973).

39 Gaines, "The Clinical Psychologist as an Expert Witness in a Personal Injury Case," 39 Marquette L. Rev' 239 (1956).

40 See, e.g., Keuper v. Wilson, 268 A.2d 753 (N.J. Super. Ch. Div. 1970), supplemented 268 A.2d 760 (N.J. Super. Ch. Div. 1970).

"1 Lower, "Psychologists as Expert Witnesses," 4 L. \& Psychol. Rev. 127 (1978).

42 See, e.g., Mills v. Board of Education, 348 F. Supp. 866 (D.D.C. 1972); Pennsyhunia ARC r. Pennsylıania, 343 F. Supp. 279 (E.D. Pa. 1972).

${ }^{43}$ See, e.g., Wyatt '. Stickney, 344 F. Supp. 387 (M.D Ala. 1972), affd sub nom. Wyatt v. Aderholt. 503 F 2d 1305 (5th Cir. 1974).

44 See. e.g., Carroll v. Cobb, 354 A.2d 355 (N.J. Super. Ct. App. Div. 1976).

is Fincher, $28 \mathrm{Am}$. Psychologist, note 33, above, at 493.

46 Halderman 1. Pennhurst State School and Hospital, 446 F. Supp. 1295 (E.D. Pa. 1977), stay denied 45/ F. Supp. 233 (E.D. Pa. 1978).

${ }^{17}$ Halderman, 446 F. Supp., above. at 1302-1312. 
As Id. at 1322 .

ty $l d$. at 1325 .

so $l d$.

$\because$ Fincher, $28,4 m$. Prycholusist, note 33. ahove, at 493.

s: Diamond and l.ouisell, "The Psychiatrist as an Expert Witness: Some Ruminations and Speculations," 63 Mic/l. L. Rel. 1335.1340 (1965):

s3 For an analysis of the more lurid sort of "gamesmanship." see Willis. "Psychiatric Testimony. Trial Gamesmanship and the Defense of Insanity," 5 San Diege) L. Rel. 32 (1968).

st See. e.s.. Suarez, "A Critique of the Psychiatrist's Role as Expert Witness." 12J.Forensic Sci. 172 (1967).

s5 See, e.g., MacDonald. Psvchiatry and the Criminal (1969).

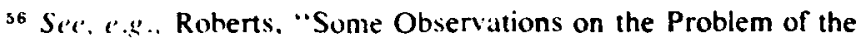
Forensic Psychiatrist," 1965 Wisc. L.. Rev'. 240.

si Sex, e's.. Van Dusen. "The Impartial Medical Expert System: The Judicial Point of View," 35 Temple L.Q. 386 (1961): Balcanoff and McGarry. "Amicus Curiae: The Role of the Psychiatrist in Pretrial Examinations," 126 Am.J. Psychiatry 90 (1969).

in See. e.g. Goldstein. "The Psychiatrist and the Legal Process: The Proposals for an Impartial Expert and for Preventive Detention." $33 \mathrm{Am} . J$. Orthepsivehiat) 123 (1963).

sy Se'e $e^{\prime} . \mathrm{s} .$, Diamond, "The Psychiatrist as Advocate." $1 \mathrm{~J}$. Psych, \& L. 5 (1973): (characterizing the respunsible expert role by the phrase "disciplined subjectivity"); Diamond. "The Fallacy of the Impartial Expert." 3 Arch. Crim. Psychodynamic's 221 (1959); Pollack, "Observations on the Adversary System and the Role of the Forensic Scientist: 'Scientific Truth ${ }^{\circ} v$. 'Legal Truth. " $18 \mathrm{~J}$. Forensic Soi. 173 (1973).

so For an explanation of why there is dual hostility between psychiatrists and attomeys, s'e Robey and Bogard, "The Compleat Forensic Psychiatrist," $126 \mathrm{Am}$. J. Psychicary 101 (1969); Sargent, "Problems in Collaboration Between Lawyers and Psychiatrists." 11 Wayne L. Rev. 697 (1965). For a more penetrating examination. s'o Goldstein, "Psychoanalysis and Jurisprudence." 77 Yale $L J$. 1053 (1968).

(1) Jonas Robitscher, for instance, quotes F.A. Whitlock's characterization of the relationship between law and medicine as the result of a "shotgun wedding" and not merely as a "mariage de conrenance." Robitscher. Pursuit of Agreement: Psychiatry and the Law 12 (1966), ciring Whitlock, Criminal Responsibility and Mental Illncss (1963).

62 Asch, Mental Disability in Civil Practice, Section 12.8 at 292 293 (1973).

:3 Schofield, "Psychology, Law and the Expert Witness." $11 \mathrm{Am}$. Psychologist 1 (1956).

it Blunt r. United States, 389 F.2d 545 (D.C. Cir. 1967).

is Record at 36. United States , B. Branner, 47I F.2d 969 (D.C. Cir. 1972), as quoted in Allen, “The Brawner. Rule - New Lyrics for an Old Tune," $1973 \mathrm{Wush.U.L.Q.67.}$

${ }^{66}$ Jeffrey. "The Psychologist as an Expert Witness on the Issue of Insanity, $10 \mathrm{Am}$. Psychologise 838 (1964).

'a Note. 8 !'ill. L. Re'.. note 16, above, at 124, n. 31.

os 63 P.S.A. \$1213. Psychologist is defined at 63 P.S.A. \$1206(a).

Cf.. e.g.. N.J. Evid. R. 26A-1: N.J.S.A. 45:14B-28.

69 In re B, 394 A.2d 419 (Pa. Sup. Ct., Oct. 5. 1978).

i) $I d$. slip op. at 22.

$\therefore / d$.

$\because 28$ P.S.A. $\$ 328$.

3 63 P.S.A. $\$ 1213$.

it Brief for American Psychiatric Association as Amicus Curiae at 20. in Linited States r. Branner. 471 F.2d 969 (D.C. Cir. 1972), as quoted in Allen, $1973 \mathrm{Wash} . U . L . Q$. note 65 , above, at 74 .

is Allen, note 65, above.

:6 See. t.g. lirginia Academy of Clinical Psychologists 1. Bhte Shield of lirginia. No. 79-1345 (4th Cir.. tiled July 24. 1979). 3 MDLR 401. $\therefore$ Asch, note 62, above, al 286.

is Louisell. "The Psychologist in Today's Legil World." 39 Minn. L. Re' 235 (1955). Louisell's thinking is reiterated in Pacht, note 17. above.

in See'. 's.. Schofield. $11.4 \mathrm{~m}$. Psy/hologist, note 63. above, at 1 (referring to "sources of stress" residing in the general nature of court proceedings"). See generally McCary. "The Psychologist as an Expert Witness in Court." 11 Am. Psychologist 8 (1956): Rice. "The Psychologist as Expert Witness," 16 Am. Psychologist 691 (1961).

*a Sargent. II Waine $L$. Rer.. note 60 , above, at 698. For what might charitably be termed bizarre advice to an expert witness faced with such a situation, see Kiger, "The Psychiatrist as an Expen Witness in Criminal Court," 24 Hosp. \& Commun. Psych. 613 (1973).

*1 Jeffrey, $19 \mathrm{Am}$. Prychologist. note 66 , above, at 838 .

\&2 Id. at 838-843.

sas Se', e.,., Brodsky, "The Mental Health Professional on the Witness Stand: A Survival Guide," in Tapp, ed., Law, Justice and the Individual in Society 269 (1977): Lower, note 41, above.

it National Institute of Mental Health. Competency \& Stand Trial and Mental Illiness 73 (1974).

*s Sie id. at 93. Cf. Group for the Advancement of Psychiatry, Misusc of Psychiatry in the Criminal Courts: Competency to Stand Trial (1974).

"Karl, 254 N.W.2d, note 25, above, at 261, quoting Casimere 1. Herman, 137 N.W.2d 73 (Wis. Sup. Ct. 1965).

${ }^{\prime 7}$ Hogan. "Licensing Mental Therapists," New York Times (July 18, 1979), at A23 (Op-ed page). Hogan is the author of the justreleased four-volume series The Regulation of Psychotherapists.

x* See. e.g.. Lezak. "The Clinical Psychologist in the Litigation Process," in George, ed., The Effective Use of Psychiatric Evidence in Civil and Criminal Litigation 137 (P.I.I. ed. 1974); Levitt. 45 Ind. L. Rey., note 16 , above, at 86.

xy Set, e.g., Fincher, $28 \mathrm{Am}$. Psychologist, note 33, above, at 494.

yo Brodsky and Robey, “On Becoming an Expert Witness: Issues of Orientation and Effectiveness." 3 Prof. Psyc/hol. 173 (1972).

y1 Cf. Halleck, “A Troubled View of Current Trends in Forensic Psychiatry," 2 J.Psych. \& L. 135 (1974).

92 Cf. Rollins, "The Forensic Psychiatrist: Conspirator, Isolationist, or Advocate?" 24 Hosp. \& Commun. Psych. 632 (1973).

93 Cf. Pollack. "Forensic Psychiatry - A Specialty," I Bull, Am. Acad. Psych. \& L. 1 (1974).

y+ See, e.g., Volume 4, Appendix. Task Panel Reports Submitted to the President's Commission on Mental Health 1359-1515 (1978). Psychologists on the Legal and Ethical Issues Task Panel were Jane Knitzer, Ed.D., Staff Associate of the Children's Defense Fund in Washington, D.C., and John Monahan, Ph.D.. Assistant Professor of Psychology. University of California at Irvine, California.

ys Barclay, "Foreword," 9 Prof. Psychol. 361 (1978) (symposium special issue: Law and Professional Psychology).

9ti Bobbitt and Hoch. "Order - and Psychologists - in the Court," $16 \mathrm{Am}$. Psychologist 152 (1961).

9: See text accompanying notes 16-17, above.

9* Gaines, note 39 , above.

yy Lezak, note 35, above.

ivu Scheflen, "The Psychologist as a Witness," 32 Pa. Bar Assn. Q. 329 (1961).

iv] Id. at 333-334.

10: "Psychiatrists and Psychologists to be Boarded as Specialists in Forensic Area," I Furensic /ssues 4 (1979). For a recent survey of all issues. see Miller. Lower and Bleechmore, "'The Clinical Psychologist as an Expen Witness on Question of Mental Illness and Competency, " 4 L. \& Psychol. Rev. 114 (1978).

1w: Scheflen, note 100. above. at 334 . 